\title{
CD45 ${ }^{\operatorname{dim}} \mathrm{CD} 34^{+} \mathrm{CD} 38^{-} \mathrm{CD} 133^{+}$cells have the potential as leukemic stem cells in acute myeloid leukemia
}

Sook-Kyoung Heo', Eui-Kyu Noh², Lan Jeong Ju', Jun Young Sung ${ }^{1}$, Yoo Kyung Jeong ${ }^{1}$, Jaekyung Cheon², Su Jin Koh', Young Joo Min ${ }^{2}$, Yunsuk Choi ${ }^{1,2^{*}}$ and Jae-Cheol Jo ${ }^{1,2^{*}}$

\begin{abstract}
Background: Leukemia stem cells (LSCS) in play an important role in the initiation, relapse, and progression of acute myeloid leukemia (AML), and in the development of chemotherapeutic drug resistance in AML. Studies regarding the detection of LSCS and the development of novel therapies for targeting them are extensive. The identification of LSCs and targeting therapies for them has been continuously under investigation.
\end{abstract}

Methods: We examined the levels of $\mathrm{CD} 45^{\mathrm{dim}} \mathrm{CD} 34^{+} \mathrm{CD} 38^{-} \mathrm{CD} 133^{+}$cells in bone marrow samples from patients with hematological malignancies and healthy controls, using four-color flow cytometry.

Results: Interestingly, the $\mathrm{CD} 45^{\mathrm{dim}} \mathrm{CD} 34^{+} \mathrm{CD} 38^{-} \mathrm{CD} 133^{+}$cells were highly expressed in the bone marrow of patients with $\mathrm{AML}$ compared to that in healthy controls $(\mathrm{HC})$. Moreover, the proportions of $\mathrm{CD} 45^{\mathrm{dim}} \mathrm{CD} 34^{+} \mathrm{CD} 38^{-} \mathrm{CD} 133^{+}$cells were also examined in diverse hematological malignancies, including $A M L, C M L, D L B C L, M M, M D S, H L, A L L$, and CLL. LSCs were prominently detected in the BMCs isolated from patients with AML and CML, but rarely in BMCs isolated from patients with DLBCL, MM, MDS, ALL, CLL, and HL. Additionally, the high CD $45^{\mathrm{dim}} \mathrm{CD} 34^{+} \mathrm{CD} 38^{-} \mathrm{CD} 133^{+}$cell counts in AML patients served as a significantly poor risk factor for overall and event free survival.

Conclusions: Therefore, our results suggest that $\mathrm{CD} 45^{\mathrm{dim}} \mathrm{CD} 34^{+} \mathrm{CD} 38^{-} \mathrm{CD} 133^{+}$cells in $\mathrm{AML}$ might potentially serve as LSCs. In addition, this cell population might represent a novel therapeutic target in AML.

Keywords: Acute myeloid leukemia, Leukemic stem cells, CD45 ${ }^{\operatorname{dim}} \mathrm{CD} 34^{+} \mathrm{CD} 38^{-} \mathrm{CD} 133^{+}$cells, Prognosis, Immunophenotyping

\section{Background}

Acute myeloid leukemia (AML) is generally regarded as a stem cell disease. It originates from a class of leukemic stem cells that are capable of self-renewal $[1,2]$. AML is a heterogeneous disease, with respect to the causative pathogenic mutations and clinical outcomes [3]. AML can progress aggressively within a short period of time and become lethal. Survival rates for adults with AML are very

\footnotetext{
* Correspondence: choiysmd@gmail.com; jcjo97@hanmail.net 'Biomedical Research Center, Ulsan University Hospital, University of Ulsan College of Medicine, Ulsan 44033, Republic of Korea

Full list of author information is available at the end of the article
}

poor despite extensive chemotherapy and/or targeted therapies, provided along with supportive care [4].

The leukemia stem cells (LSCs) in AML play an important role in the development, relapse and progression of leukemia, and in the development of chemotherapeutic drug resistance in AML [5]. Recent studies have suggested that LSCs are capable of giving rise to identical daughter cells that can differentiate into other cells and maintain AML [6, 7]. Rhenen et al. showed that a high percentage of $\mathrm{CD} 34^{+} \mathrm{CD} 38^{-}$stem cells at diagnosis significantly correlated with a high minimal residual disease frequency and subsequently to relapse in AML patients.

(C) The Author(s). 2020 Open Access This article is licensed under a Creative Commons Attribution 4.0 International License, which permits use, sharing, adaptation, distribution and reproduction in any medium or format, as long as you give appropriate credit to the original author(s) and the source, provide a link to the Creative Commons licence, and indicate if changes were made. The images or other third party material in this article are included in the article's Creative Commons licence, unless indicated otherwise in a credit line to the material. If material is not included in the article's Creative Commons licence and your intended use is not permitted by statutory regulation or exceeds the permitted use, you will need to obtain permission directly from the copyright holder. To view a copy of this licence, visit http://creativecommons.org/licenses/by/4.0/ The Creative Commons Public Domain Dedication waiver (http://creativecommons.org/publicdomain/zero/1.0/) applies to the data made available in this article, unless otherwise stated in a credit line to the data. 
These cell populations directly correlated with poor survival $[8,9]$.

Identification and characterization of the LSC population is one of the best ways to develop treatment strategies and to improve treatment outcomes in patients with AML and other malignant diseases [3]. Extensive basic research on the identification and targeting of LSCs is being done globally. Many scientists are interested in this area and have found appropriate biological markers for LSC population in AML, including $\mathrm{CD}^{+} 4^{+} \mathrm{CD} 38^{-}$cells $[10,11], \mathrm{CD}^{+} 4^{+}$lin $^{-}$cells [12], $\mathrm{CD} 4^{+} \mathrm{Thy}^{+} \mathrm{CD} 38^{\text {low }}$ cells [13], CD $34^{+} \mathrm{CD} 117^{+}$cells [14], $\mathrm{CD}^{+} 4^{+} \mathrm{CD} 38^{-} \mathrm{CD} 123^{+}$cells [15-17], $\mathrm{CD}^{+} 4^{+} \mathrm{CD} 38^{-} \mathrm{CD} 123^{+}$ $\mathrm{CD}^{+}{ }^{+}$cells [18], CD34 ${ }^{+} \mathrm{CD} 38^{-} \mathrm{C}$-type lectin-like molecule-1 $(\mathrm{CLL}-1)^{+}$cells [19], CD34 ${ }^{+} \mathrm{CD} 38^{-} \mathrm{CD}^{-} 6^{+}$cells [20], CD $34^{+} \mathrm{CD} 38^{-} \mathrm{CD} 45^{- \text {low }}$ cells [21], CD34/CD123/CD25/ $\mathrm{CD} 9^{+}$[5], etc. The $\mathrm{CD} 34^{+} \mathrm{CD} 38^{-}$progenitor cells express varying levels of the target receptors, CD33, CD133, and ckit (CD117) [22]. However, most of the studies have not provided any conclusive data. Therefore, we analyzed the findings from published studies and identified new combinations that could help detect LSCs. We developed this method using the basic $\mathrm{CD} 34^{+} \mathrm{CD} 38^{-}$markers to which novel antigens such as CD45 $5^{\mathrm{dim}}$ and CD133 were added. In this study, we developed a four-color flow cytometric analysis method, and measured the levels of LSCs in bone marrow cells isolated from AML patients. Our findings suggest that $\mathrm{CD} 45^{\mathrm{dim}} \mathrm{CD} 34^{+} \mathrm{CD} 38^{-} \mathrm{CD} 133^{+}$cells exhibit similar potential as that of LSCs in AML patients.

\section{Methods}

\section{Reagents}

Mouse anti-human CD45-FITC (Clone 2D1, Cat No. 347463), mouse anti-human CD34-PE [Clone 8G12 (also known as HPCA2), Cat No. 348057], mouse anti-human CD38-PE-Cy ${ }^{\mathrm{mm}} 5$ (Clone HIT2, Cat No. 555461), and appropriated isotype control antibodies were purchased from BD Biosciences (San Diego, CA, USA). Mouse anti-human CD133-APC (Clone CD133, Cat No. 130090-826) was obtained from Miltenyi Biotec (San Diego, CA, USA).

\section{Patient samples}

We analyzed bone marrow samples collected from 87 patients who were newly diagnosed with AML $(n=40)$, chronic myeloid leukemia (CML, $n=6)$, diffuse large Bcell lymphoma (DLBCL, $n=19$ ), multiple myeloma $(\mathrm{MM}, n=10)$, myelodysplastic syndrome (MDS, $n=5)$, Hodgkin lymphoma (HL, $\mathrm{n}=4)$, acute lymphocytic leukemia (ALL, $n=3$ ), or chronic lymphocytic leukemia (CLL, $n=2)$. Control bone marrows were obtained to rule out hematologic disorders but proven to be normal marrows from 27 healthy donors at Ulsan University Hospital, Ulsan South Korea. Baseline clinical characteristics of 40 patients with AML are summarized in
Supplementary Table 1. Other patient characteristics (expect AML) are summarized in Supplementary Table 2.

\section{Isolation of bone marrow cells}

The bone marrow cells (BMCs) were isolated by the density gradient method, as previously described [23]. In brief, BMCs were isolated via density gradient centrifugation at $400 \times g$ using Lymphoprep (Axis-Shield, Oslo, Norway; density, $1.077 \mathrm{~g} / \mathrm{mL}$ ). They were washed with phosphate-buffered saline (PBS).

\section{Flow cytometric phenotypic analysis}

The BMCs were collected and washed twice with FACS buffer (PBS containing 0.3\% BSA and $0.1 \% \mathrm{NaN}_{3}$ ). The total bone marrow cell number used in the experiment was $4 \times 10^{6}$ cells. Cells were incubated with four antibodies against each cell surface antigen, including CD45, CD34, CD38, and CD133 on ice for $30 \mathrm{~min}$. First, live BMCs were collected, and SSC ${ }^{\text {low }}$ and $\mathrm{CD} 45^{\text {dim }}$ cells were gated, as shown in Fig. 1a and b. And we always draw gates with the same criteria and select cells in the same section. The criteria are as follows: R1 Gate: live cells; R2 Gate: SSC-H, 100-500 and FL2-H, $10^{1}-10^{2}$; R3 Gate: FL2-H, $10^{2}-10^{4}$, FL3-H, $10^{0}-10^{1}$. The BMCs were incubated with three combinations of monoclonal antibodies (mAbs) on ice for $30 \mathrm{~min}$; these included isotype control 1 (mouse anti-human CD45-FITC, mouse IgG$\mathrm{PE}$, mouse IgG-PE CY5, and mouse IgG-APC), isotype control 2 (mouse anti-human CD45-FITC, mouse antihuman CD34-PE, mouse anti-human CD38-PE CY5, and mouse IgG-APC), and sample (mouse anti-human CD45-FITC, mouse anti-human CD34-PE, mouse antihuman CD38-PE CY5, and mouse human CD133-APC), as shown in Fig. 1c and Fig. 1d. Cells were then washed twice with FACS buffer and analyzed using the FACSCalibur flow cytometer and CellQuest Pro software (BD Bioscience) as shown Fig. 1. Finally, the counts of $\mathrm{CD} 45^{\mathrm{dim}} \mathrm{CD} 4^{+} \mathrm{CD} 38^{-} \mathrm{CD} 133^{+}$cells, $\mathrm{CD} 133$ positive cells among the R1, R2, R3-gated cells were measured, and the results were expressed as percentage change from the basal conditions including the isotype control 2 . The 40,000 cells were used for flow cytometric acquisition in each sample tube.

\section{ELISA for cytokine measurement}

Cell-free plasma from bone marrow samples of patients with AML was collected and frozen at $-80^{\circ} \mathrm{C}$. Plasma interleukin (IL)-1 $\beta$, IL-6, IL-17, and IL-23 levels were measured using ELISA kits according to the manufacturer's introductions (R\&D Systems).

\section{Statistics}

The data presented here represent the mean \pm standard error of mean (SEM) of at least three independent 
A

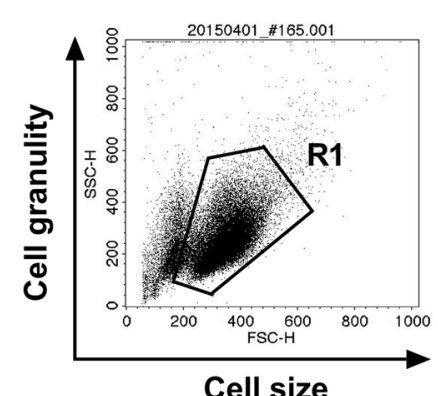

Cell size

\section{B R1-gated}

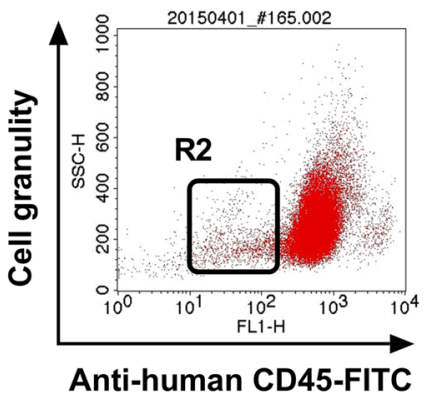

C R1, R2-gated

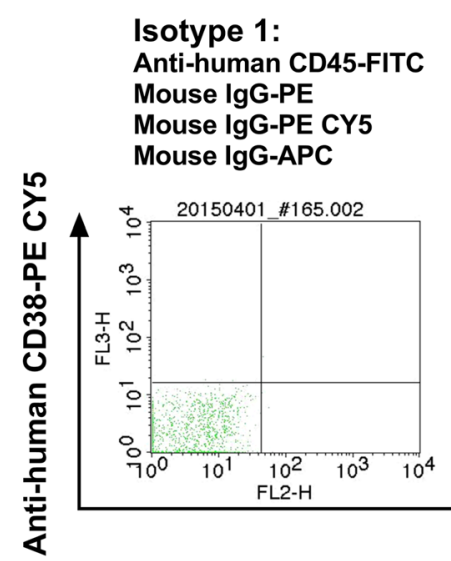

Isotype 2:

Anti-human CD45-FITC Anti-human CD34-PE Anti-human CD38-PE CY5 Mouse IgG-APC

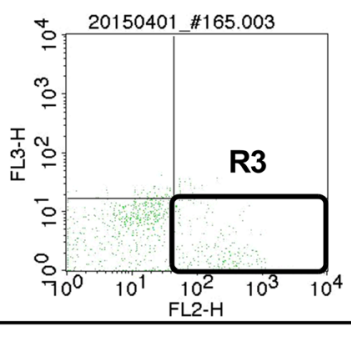

Anti-human CD34-PE
Sample:

Anti-human CD45-FITC

Anti-human CD34-PE

Anti-human CD38-PE CY5

Anti-human CD133-APC

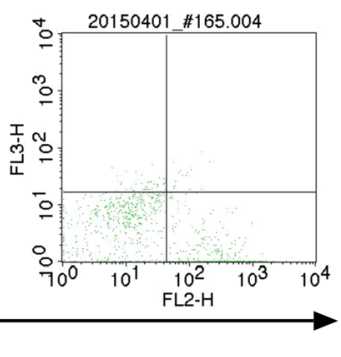

\section{R1, R2, R3-gated}

Overlay of isotype $\mathbf{2}$ and sample

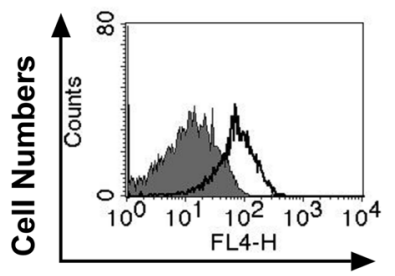

Anti-human CD133-APC

Fig. 1 The process of four-color staining flow cytometry using monoclonal antibodies. The BMCs were collected and washed twice with FACS buffer. Cells were incubated with four antibodies against cell surface antigens, including CD45, CD34, CD38, and CD133 on ice for 30 min. a, b The live BMCs were collected, and SSClow and CD45 dim cells were gated. $\mathbf{c}, \mathbf{d}$ The BMCs were incubated with three types of combinations of monoclonal antibodies (mAbs) on ice for 30 min such as isotype control 1 (mouse anti-human CD45-FITC, mouse lgG-PE, mouse IgG-PE CY5 and mouse IgG-APC), isotype control 2 (mouse anti-human CD45-FITC, mouse anti-human CD34-PE, mouse anti-human CD38-PE CY5, and mouse lgG$A P C$ ), and sample (mouse anti-human CD45-FITC, mouse anti-human CD34-PE, mouse anti-human CD38-PE CY5, and mouse human CD133-APC). Cells were then washed twice with FACS buffer and analyzed using the FACSCalibur flow cytometer and CellQuest Pro software (BD Bioscience). Finally, the levels of $\mathrm{CD} 45^{\mathrm{dim}} \mathrm{CD} 34^{+} \mathrm{CD} 38^{-} \mathrm{CD} 133^{+}$cells, CD133 positive cells among the R1, R2, R3-gated cells were measured and the results were expressed as percentage change from the baseline conditions including isotype control 2 . The filled histogram represents the isotype control 2 , and the empty histogram represents $\mathrm{CD} 45^{\mathrm{dim}} \mathrm{CD} 34^{+} \mathrm{CD} 38^{-} \mathrm{CD} 133^{+}$cells

experiments. All values were evaluated by one-way analysis of variance followed by Turkey range tests implemented in GraphPad Prism 7.0. Differences were considered significant at $P<0.05$. For patients with AML, continuous variables were compared using the
Student's $t$-test, whereas categorical variables were analyzed using the Pearson chi-square test or Fisher's exact test. Overall survival (OS) was calculated from the date of HCT to the date of death or last follow-up. Event-free survival (EFS) was defined from the date of HCT to the 
date of relapse or death from any cause. Survival probabilities were estimated by the Kaplan-Meier method. Univariate and multivariate analyses for OS, EFS, and relapse probability were performed using the log rank test and Cox proportional hazards model, respectively. The following variables were included in univariate analyses: $\mathrm{CD} 45^{\mathrm{dim}} \mathrm{CD} 34^{+} \mathrm{CD} 38^{-} \mathrm{CD} 133^{+}$cell proportion, age, white blood cell (WBC) count, platelet count, bone marrow blast percentage, cytogenetic risk groups, chemotherapeutic regimens, and immunophenotyping including $\mathrm{CD} 7, \mathrm{CD} 33$, CD34, and HLA-DR. Variables with a $P$-value $<0.1$ in the univariate analyses were included in the multivariate analyses. The statistical analyses were performed with SPSS version 21.0 software (IBM Corp., Armonk, NY). For all analyses, the $P$-values were two-sided; a $P$-value of $<0.05$ was considered statistically significant.

\section{Results}

CD $45^{\text {dim }} \mathrm{CD} 34^{+} \mathrm{CD} 38^{-} \mathrm{CD} 133^{+}$cells are present in high numbers in the bone marrow of patients with acute myeloid leukemia

The work flow of the four-color flow cytometry experiments using monoclonal antibodies (mAbs) is shown in Fig. 1. As shown in Fig. 1a and b, live BMCs were collected and $\mathrm{SSC}^{\text {low }} / \mathrm{CD} 45^{\mathrm{dim}}$ cells were obtained. The BMCs were stained with various combinations of monoclonal antibodies for $30 \mathrm{~min}$ such as isotype 1, isotype 2, and sample (Fig. 1c). The CD133 positive cells in the R1, R2, R3-gated cells were measured using flow cytometry, and the results were expressed as percentage changes from the isotype 2 (Fig. 1d). A total of 40 AML patients were examined for the expression of the target antigens, $\mathrm{CD} 45^{\mathrm{dim}} \mathrm{CD} 34^{+} \mathrm{CD} 38^{-} \mathrm{CD} 133^{+}$on the surface of BMCs. These cells were present in high numbers in the bone marrow samples isolated from patients with AML, but not in those of healthy controls (Fig. 2). These results indicated that $\mathrm{CD} 45^{\mathrm{dim}} \mathrm{CD} 34^{+} \mathrm{CD} 38^{-} \mathrm{CD} 133^{+}$cells in bone marrow are potential AML stem cells.

\section{Elevated IL-1 $\beta$, IL-6, IL-17 and IL-23 cytokine production of plasma in patients with AML}

Recently, Th17 related cytokines such as IL-1 $\beta$, IL-6, IL17, IL-21, IL-22, and IL-23 play crucial roles in the pathogenesis of many diseases, including inflammatory diseases, autoimmune diseases, and cancers [24]. They have been shown related to Th17 cells. Especially, elevated frequencies of these cytokines in patients with AML have been associated with prognosis [25]. Therefore, we examined the levels of IL-1 $\beta$, IL-6, IL-17 and IL-23 in the bone marrow plasma samples, which were matched to BMCs in AML patients. Plasma samples from the AML patients exhibited higher levels of IL-1 $\beta$, IL-6, IL-17, and IL-23 than those from healthy controls (Fig. 3).

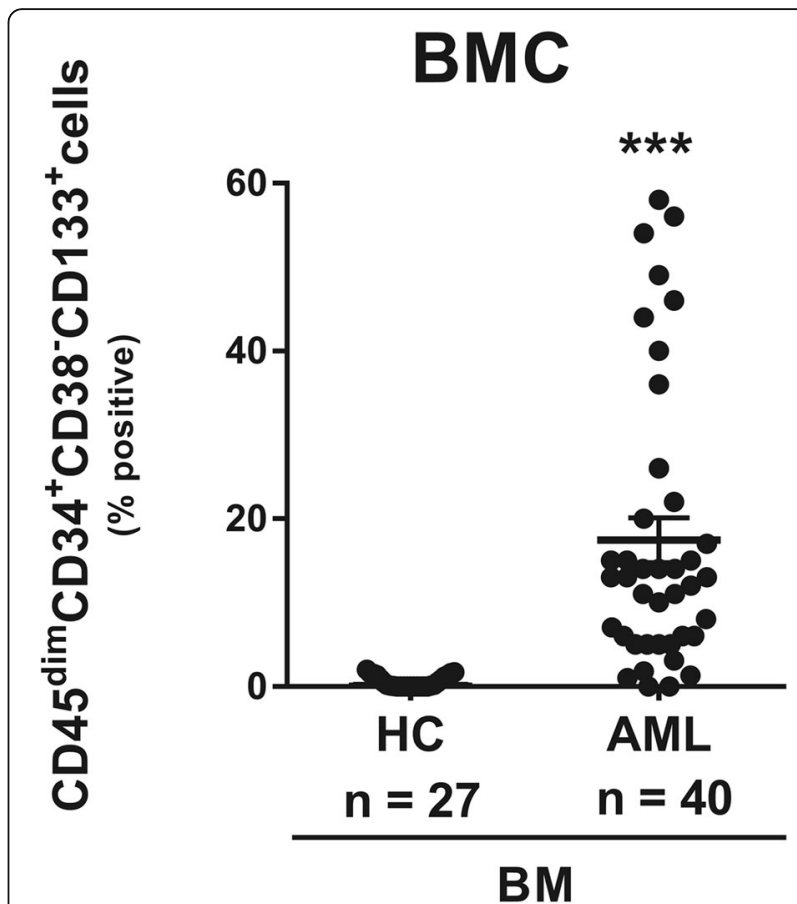

Fig. 2 The $\mathrm{CD} 45^{\mathrm{dim}} \mathrm{CD} 34^{+} \mathrm{CD} 38^{-} \mathrm{CD} 133^{+}$cells are highly expressed in the bone marrow of patients with $\mathrm{AML}$, but not in healthy controls. Bone marrow cells from healthy controls and AML patients were examined for the expression of the target antigens, CD45 ${ }^{\text {dim }} \mathrm{CD} 34^{+}$CD $38^{-}$CD $133^{+}$cells. Data represent mean \pm SEM representing three independent experiments from different $\mathrm{AML}$ patients. Significantly different from the control $\left({ }^{*}\right) ;{ }^{* *}, P<0.001$. HC, healthy controls; AML, acute myeloid leukemia patients

The $\mathrm{CD} 45^{\mathrm{dim}} \mathrm{CD} 34^{+} \mathrm{CD} 38^{-} \mathrm{CD} 133^{+}$cells are prominently detected in the bone marrow of patients with AML and CML

As shown in Fig. 4, the $\mathrm{CD} 45^{\mathrm{dim}} \mathrm{CD} 34^{+} \mathrm{CD} 38^{-} \mathrm{CD} 133^{+}$ cells were examined by four-color flow cytometry in diverse hematological malignancies including AML $(n=$ 40), CML $(n=6)$, DLBCL $(n=19), \mathrm{MM}(n=10)$, MDS, $(n=5)$, HL $(\mathrm{n}=4)$, ALL $(n=3)$, and CLL $(n=2)$. These cells are significantly detected in the bone marrow of patients with AML and CML, but not in those with DLBCL, MM, MDS, ALL, CLL, and HL. These results indicated that $\mathrm{CD} 45^{\mathrm{dim}} \mathrm{CD} 34^{+} \mathrm{CD} 38^{-} \mathrm{CD} 133^{+}$cells in bone marrow are potential of AML stem cells. In addition, these cells might be used for the detection of AML stem cells.

\section{Clinical characteristics according to levels of the CD45 ${ }^{\text {dim }} \mathrm{CD}_{34}{ }^{+} \mathrm{CD} 38^{-} \mathrm{CD} 133^{+}$cells}

CD $34^{+}$AML and CD34- AML among 36 AML patients evaluable for CD34 expression was noted in 30 patients and 6 patients, respectively. The proportion of $\mathrm{CD} 45^{\mathrm{dim}} \mathrm{CD} 34^{+} \mathrm{CD} 38^{-} \mathrm{CD} 133^{+}$cells in CD34- AML were significantly lower than CD34 ${ }^{+}$AML (median, 5.0\% [range, $1-14 \%$ ] vs. $13.5 \%$ [range, 1.8-58\%], $P=0.001$, 


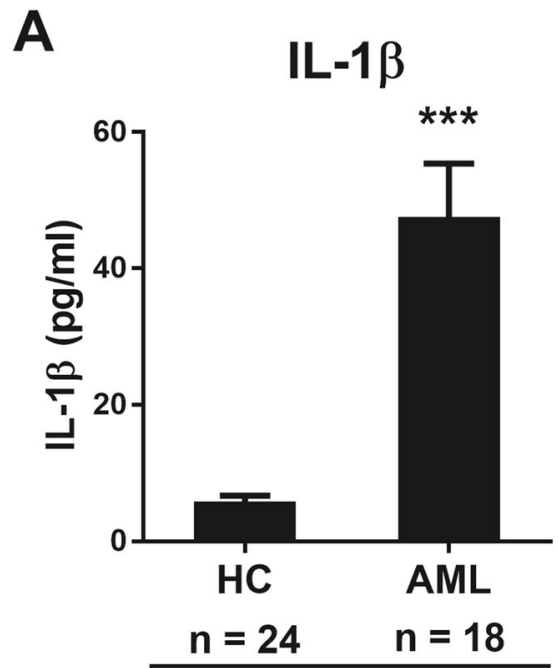

BM

C

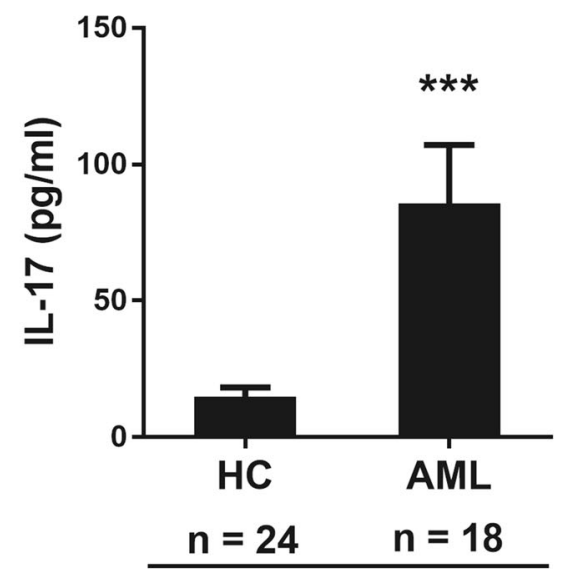

BM
B IL-6

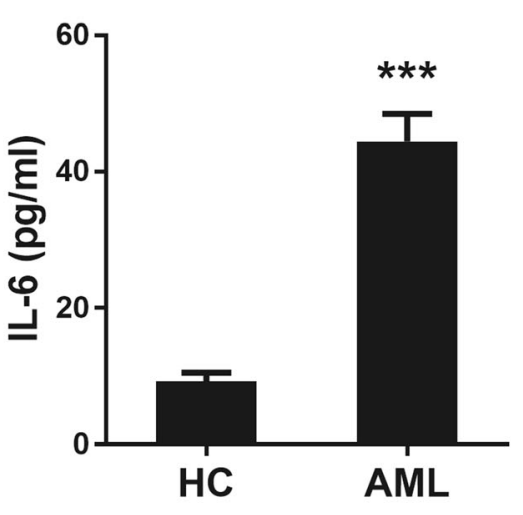

$\mathrm{n}=\mathbf{2 4} \mathrm{n}=18$

BM

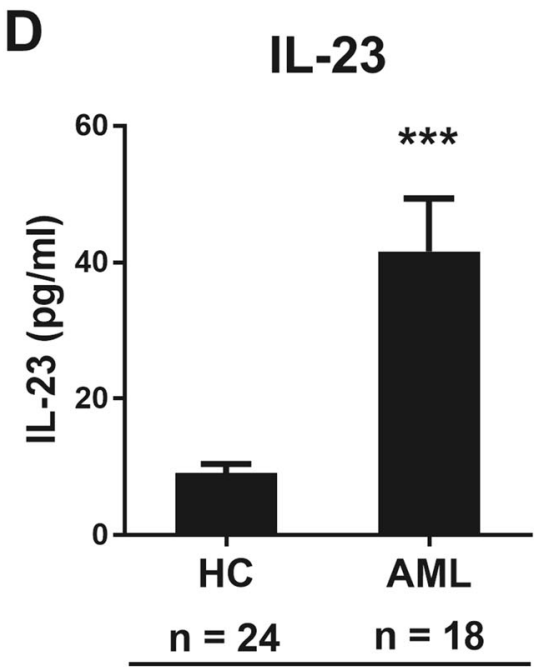

BM

Fig. 3 Quantification of the cytokines present in the plasma of healthy controls and AML patients. Cell-free plasma from bone marrow samples of AML patients was collected and frozen at $-80^{\circ} \mathrm{C}$. Plasma interleukin (IL)-1 $13, \mathrm{IL}-6, \mathrm{IL}-17$, and IL-23 levels were measured using ELISA kits according to manufacturer's introductions (R\&D Systems). Data represent mean \pm SEM from three independent experiments in different AML patients. Significantly different from the control $(*) ; * *, P<0.001$. HC, healthy controls; AML, acute myeloid leukemia patients; BM, bone marrow

respectively). And $\mathrm{CD} 34^{-}$AML showed tendency to have lower proportion of $\mathrm{CD} 45^{\mathrm{dim}} \mathrm{CD} 34^{+} \mathrm{CD} 38^{-} \mathrm{CD} 133^{+}$cells. FLT3-ITD mutation was rarely found in AML patients with higher counts of $\mathrm{CD} 45^{\mathrm{dim}} \mathrm{CD} 34^{+} \mathrm{CD} 38^{-} \mathrm{CD} 133^{+}$cells ( $\left.\geq 10 \%\right)$

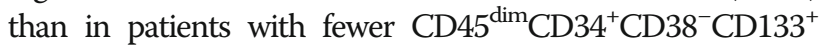
cells $(<10 \%) \quad(0 \%$ vs. $23.1 \%$, respectively, $P=0.031)$. In addition, higher counts of $\mathrm{CD} 45^{\mathrm{dim}} \mathrm{CD} 34^{+} \mathrm{CD} 38^{-} \mathrm{CD} 133^{+}$ cells ( $\geq 20 \%$ ) were significantly associated with lower levels of IL-17, as compared to lower $\mathrm{CD} 45^{\mathrm{dim}} \mathrm{CD} 34^{+} \mathrm{CD} 38^{-} \mathrm{CD} 133^{+}$ cells $(<20 \%)(118.0$ vs. $35.0 \mathrm{pg} / \mathrm{ml}$, respectively, $P=0.028)$. However, there was no significant difference in IL-1 $1, \mathrm{~L}-6$, and IL-23 levels based on the population of $\mathrm{CD} 45^{\mathrm{dim}} \mathrm{CD} 34^{+} \mathrm{CD} 38^{-} \mathrm{CD} 133^{+}$cells.
High proportion of the $\mathrm{CD} 45^{\mathrm{dim}} \mathrm{CD} 34^{+} \mathrm{CD} 38^{-} \mathrm{CD} 133^{+}$cells predicts poor survival in AML patients

When we divided AML patients into three groups based on the percentage of $\mathrm{CD} 45^{\mathrm{dim}} \mathrm{CD} 34^{+} \mathrm{CD} 38^{-} \mathrm{CD} 133^{+}$cells $(<10 \%, 10-40 \%$, and $\geq 40 \%)$, univariate analysis revealed that the 2-year OS rate was $64.3,57.9$, and $0 \%$, respectively $(P<0.001)$ and the 2 -year EFS was $62.3,37.2$, and $0 \%(P=0.002)$, respectively (Supplementary Table 3 ). Among the three groups $\left(\mathrm{CD} 45^{\mathrm{dim}} \mathrm{CD} 34^{+} \mathrm{CD} 38^{-} \mathrm{CD} 133^{+}\right.$ cell proportions $<10 \%, 10-40 \%$, and $\geq 40 \%$ ), no significant differences were observed in baseline clinical factors including age $(P=0.085)$, white blood cell count $(P=$ 0.397), platelet count $(P=0.737)$, and chemotherapy 


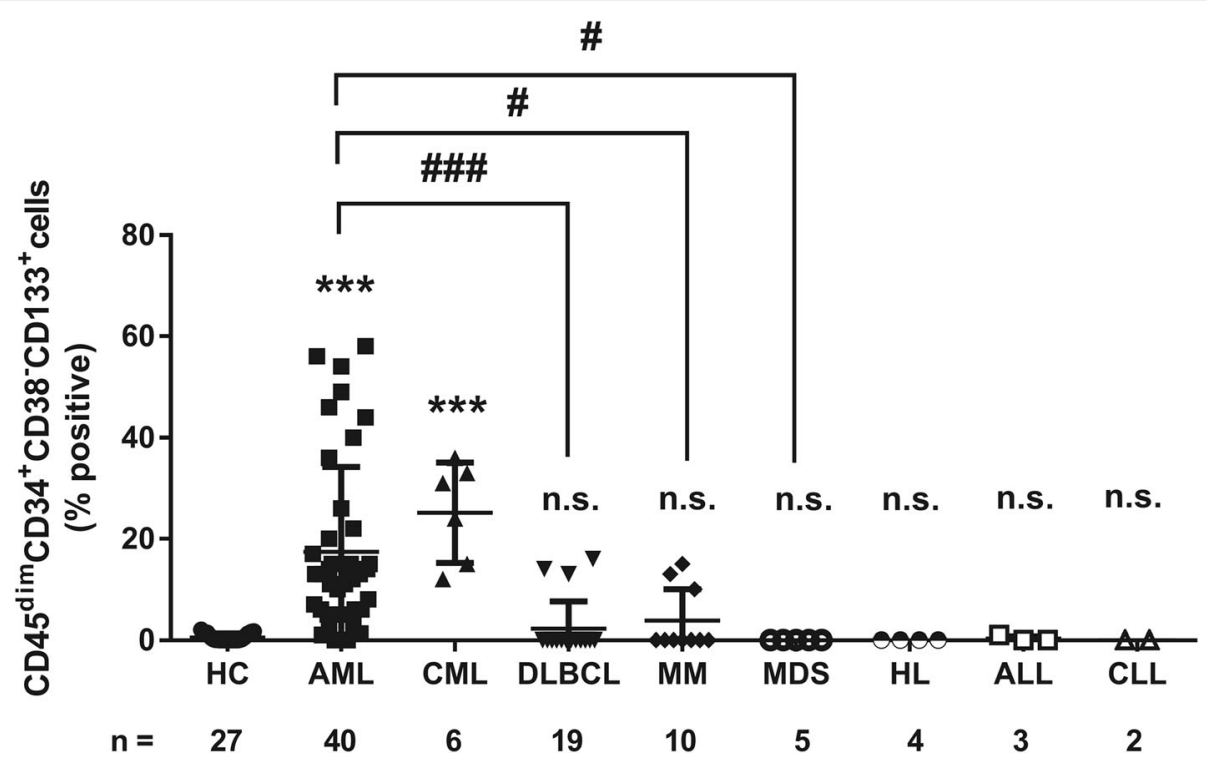

Fig. 4 The $C D 45^{\text {dim }} \mathrm{CD} 34^{+} \mathrm{CD} 38^{-} \mathrm{CD} 133^{+}$cells are prominently detected in bone marrow of patients with $\mathrm{AML}$ and CML. As shown in Fig. 1, the

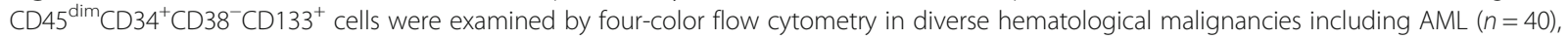
$\operatorname{CML}(n=6), \operatorname{DLBCL}(n=19), \mathrm{MM}(n=10), \operatorname{MDS},(n=5), \mathrm{HL}(n=4), \operatorname{ALL}(n=3)$, and CLL $(n=2)$. Data represent mean \pm SEM from three independent experiments in different AML patients. Significantly different from the control (*) or AML (\#); \#: $P<0.05$.; **, \#\#\#: $P<0.001$. HC, healthy controls; AML, acute myeloid leukemia; CML, chronic myeloid leukemia; DLBCL, diffuse large B-cell lymphoma; MM, multiple myeloma; MDS, myelodysplastic syndrome; HL, Hodgkin lymphoma; ALL, acute lymphocytic leukemia; CLL, chronic lymphocytic leukemia

intensity $(P=0.158)$. Univariate analyses for OS and EFS in patients with AML revealed that older age ( $>60$ years) was significantly associated with worse OS than younger age $(32.8 \%$ vs. $75 \%$ at 2 -year, respectively, $P=0.041)$ (Supplementary Table 3). In addition, patients with higher marrow blast $\%(\geq 60 \%)$ showed significantly lower OS rates than those with lower marrow blast \% $(<60 \%)$ (36.7\% vs. $66.7 \%, P=0.038$ ) (Supplementary Table 3 ). Patients who were treated with intensive chemotherapy showed significantly better OS than those treated with hypomethylating agents $(57.8 \%$ vs. $30.0 \%, P=0.012)$. When we took into consideration other clinical parameters in univariate and multivariate analyses, higher percentage of $\mathrm{CD} 45^{\mathrm{dim}} \mathrm{CD} 34^{+} \mathrm{CD} 38^{-} \mathrm{CD} 133^{+}$cells $(\geq 40 \%)$ was found to be an independent prognostic factor for OS (hazard ratio $[\mathrm{HR}], 6.052, P=0.005)$ and EFS (HR, 9.028, $P=0.002$ ) (Fig. 5. and Table 1). In addition, higher BM blast $(\%) \geq 60 \%(\mathrm{HR}, 2.607<P=0.049)$ and chemotherapy intensity (hypomethylating agents vs. intensive chemotherapy) (HR, 4.058, $P=0.010$ ) were significant prognostic factors for $\mathrm{OS}$ in multivariate analysis.

\section{Discussion}

The hypothesis that cancer stem cells including LSCs are responsible for the initiation, relapse, and drug resistance of cancers has caused a great deal of excitement in this area of research. The importance of cancer stem cells has been demonstrated in a variety of tumors [6, 25-29]. Especially, LSCs have unlimited capacity of self-renewal and are responsible for the maintenance of leukemia. Because selective eradication of LSCs could lead to considerable therapeutic benefits, there has been an interest in the identification and characterization of the LSC population that controls their development [30,31]. Therefore, studies related to prognostically relevant and potentially reliable molecular targets are needed.

AML is a hematopoietic disease that is characterized by clonal growth and the accumulation of myelopoietic progenitor cells [31]. It is a devastating disease that is mostly incurable [4]. Moreover, the treatment for AML involves intense cytotoxic treatment as approximately $70 \%$ of the patients with AML are refractory to initial therapy or undergo relapse [2]. This is at least partially driven by the chemo-resistant nature of the LSCs that maintain the disease. Therefore, novel anti-LSC therapies could decrease the number of relapses and improve survival.

The first LSC compartment that was described had the $\mathrm{CD}_{34}{ }^{+} \mathrm{CD} 38^{-}$immunophenotype $[1,11]$. The $\mathrm{CD} 34^{+} \mathrm{CD} 38^{-}$compartment was shown to contain both CD $34^{+} \mathrm{CD} 38^{-}$LSCs and normal hematopoietic stem cells (HSCs) [13]. Mawali et al. have proposed that CD $34^{+} \mathrm{CD} 38^{-} \mathrm{CD} 123^{+}$cells are AML LSCs [17]. In the present study, the $\mathrm{CD} 45^{\mathrm{dim}} \mathrm{CD} 34^{+} \mathrm{CD} 38^{-} \mathrm{CD} 133^{+}$cells were examined by four-color flow cytometry to define a more specific and prognostically significant LSC population (Fig. 1).

In the present study, CD $34^{+}$AML was found in $75 \%$ of patients with AML and 6 patients had CD34- AML. 


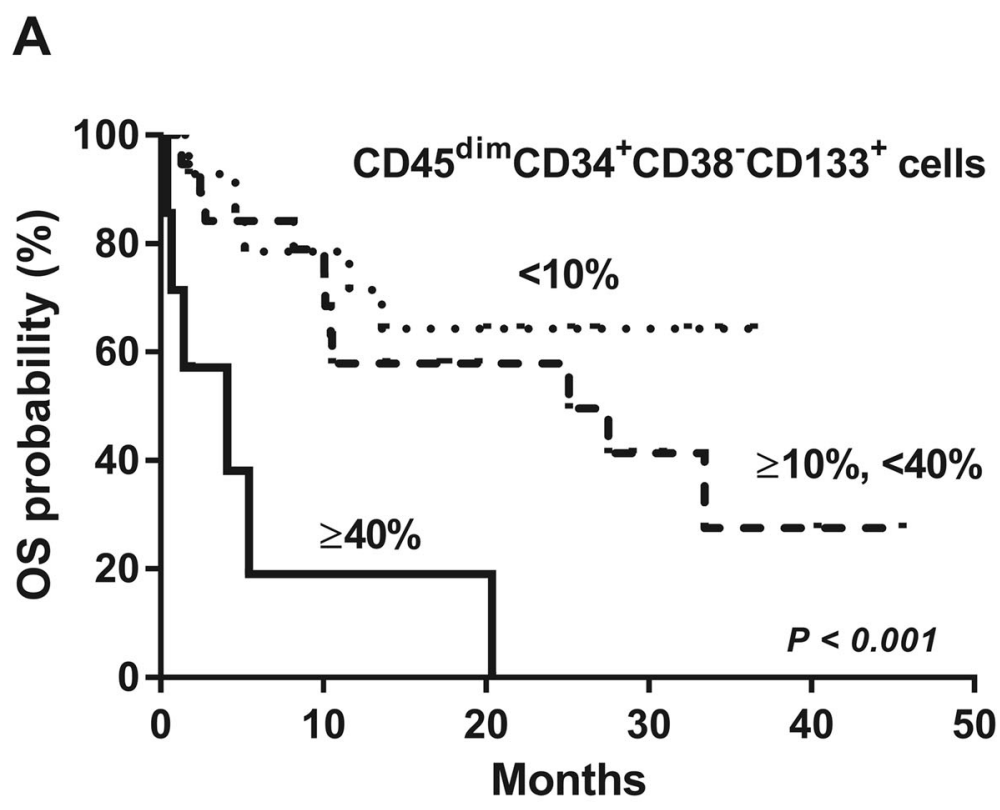

B

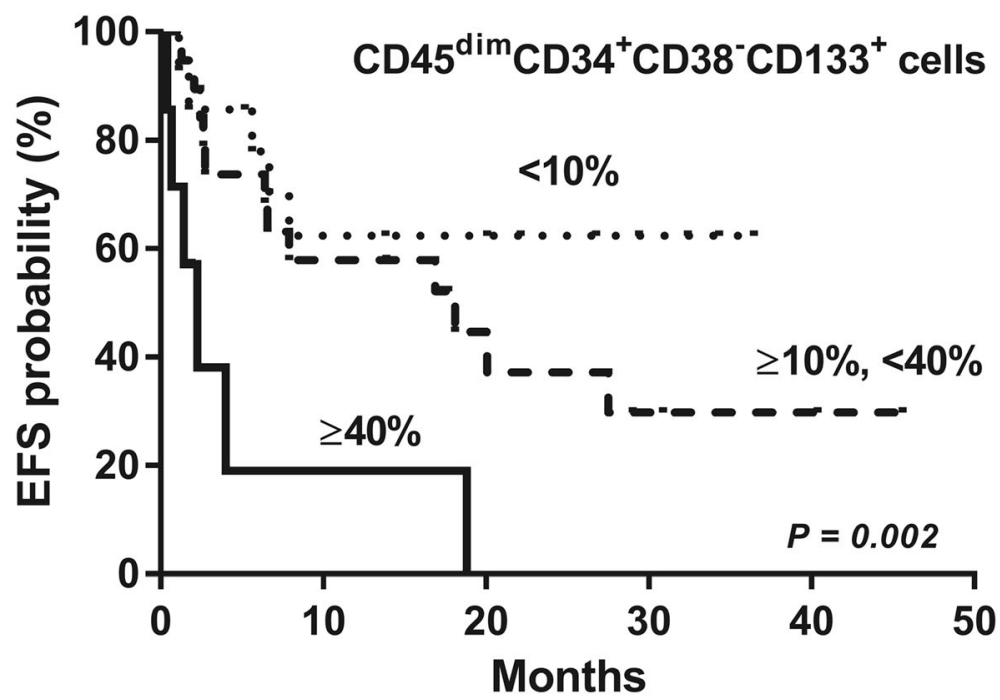

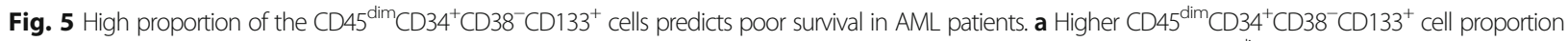
was significantly associated with worse OS $(P<0.001)$. b Poor EFS was significantly associated with higher proportion of $C D 45^{\text {dim }} C D 34^{+} C D 38^{-} C D 133^{+}$cells $(P=0.002)$

The clinical implications of $\mathrm{CD} 45^{\mathrm{dim}} \mathrm{CD} 34^{+} \mathrm{CD} 38^{-} \mathrm{CD} 133^{+}$ cells might be different in CD34- AML. The CD34- AML had lower proportion of $\mathrm{CD} 45^{\mathrm{dim}} \mathrm{CD} 34^{+} \mathrm{CD} 38^{-} \mathrm{CD} 133^{+}$ cells. Even though we could not evaluate prognostic impact of $\mathrm{CD} 45^{\mathrm{dim}} \mathrm{CD} 34^{+} \mathrm{CD} 38^{-} \mathrm{CD} 133^{+}$cells in $\mathrm{CD} 34^{-}$ AML due to small number of patients, some portion of CD $45^{\text {dim }}{ }^{-} \mathrm{CD} 34^{+} \mathrm{CD} 38^{-} \mathrm{CD} 133^{+}$cells in CD34 $4^{-}$AML might contain normal hematopoietic stem cells as well as LSCs.
CD133 has been reported to be a cancer stem cell marker in solid tumors [14, 32-34]. Several studies have shown that $\mathrm{CD} 133$ positive cells have the capacity for selfrenewal, differentiation, high proliferation, and forming tumors in xenografts $[33,34]$. Although the precise function of CD133 remains unknown, it is associated with aggressive cancers and poor prognosis. CD133 is known to be required for tumor growth and survival [14, 29, 32]. 
Table 1 Multivariate analysis for patients with acute myeloid leukemia

\begin{tabular}{|c|c|c|c|c|}
\hline & HR for OS & $P$-value & HR for EFS & $P$-value \\
\hline \multicolumn{5}{|l|}{$\mathrm{CD} 5^{\operatorname{dim}} \mathrm{CD} 4^{+} \mathrm{CD} 38^{-} \mathrm{CD} 133^{+}$} \\
\hline$<10 \%(n=14)$ & 1 & & 1 & \\
\hline $10-<40 \%(n=19)$ & 1.859 & 0.276 & 2.731 & 0.089 \\
\hline$\geq 40 \%(n=7)$ & 6.052 & 0.005 & 9.028 & 0.002 \\
\hline \multicolumn{5}{|l|}{ BM blast (\%) } \\
\hline$<60 \%(n=16)$ & 1 & & - & - \\
\hline$\geq 60 \%(n=24)$ & 2.607 & 0.049 & & \\
\hline \multicolumn{5}{|l|}{ Chemotherapy } \\
\hline Intensive chemotherapy $(n=30)$ & 1 & & 1 & \\
\hline Hypomethylating agent $(n=10)$ & 4.058 & 0.010 & 4.829 & 0.010 \\
\hline
\end{tabular}

$H R$ hazard ratio, OS overall survival, EFS event free survival

However, in hematological malignancies including AML, the clinical implications of CD133 expression are not well known. Interestingly, CD $45^{\mathrm{dim}} \mathrm{CD} 34^{+} \mathrm{CD} 38^{-} \mathrm{CD} 133^{+}$cells are present in more numbers in the bone marrow of patients with AML, but not in healthy controls (Fig. 2). In a further study, only CD133 expression in AML need to be investigated if CD133 marker positivity regardless of $\mathrm{CD} 4^{+} \mathrm{CD} 38^{-}$might be a significant marker for discriminating LSC and a prognostic biomarker. Moreover, the asynchronism of $\mathrm{CD} 133^{+}$expression should be also evaluated in $\mathrm{CD}^{-} 4^{-} \mathrm{AML}$ in the future. In other lymphoid hematologic malignancies such as lymphoma, MM, ALL, and CLL than AML, there could be some differences according to the percentages of both malignant cells and $\mathrm{CD} 34^{+} \mathrm{CD} 38^{-}$compartments within bone marrows because of niche competition between two cell populations.

We also found increased production of IL-1 $\beta$, IL-6, IL17 and IL-23 in the bone marrow microenvironment of AML patients at the time of diagnosis (Fig. 3). These findings suggest that IL-1 $\beta$, IL-6, IL-17 and IL-23 may be associated with leukemogenesis or pathophysiology of AML. Carey et al. also reported that IL-1 and IL-1 $\beta$ might be associated with AML cell growth [35]. IL-3 plays a key role within the network of cytokines involved in the regulation of hematopoiesis and leukemic blast formation. However, IL-3 has no prognostic significance [20]. As expected, the plasma samples from the AML patients at diagnosis exhibited higher levels of Th17 related cytokines, including IL-1 $\beta$, IL-6, IL-17 and IL-23, than those from healthy controls (Fig. 3). To be honest with you, we expected these cytokines to have some degree of association with LSCs, but it was difficult to find the correlation in the experimental results. More specifically, the prognostic impact of IL-17 in AML is not clear, although higher serum IL-17 levels have been reported to be an adverse prognostic factor of AML in a univariate analysis of IL-17 by Han et al. [25]. In our results, however, IL-17 did not seem to have an adverse impact on prognosis of AML, because IL-17 was inversely correlated with the percentage of $\mathrm{CD} 45^{\mathrm{dim}} \mathrm{CD} 34^{+} \mathrm{CD} 38^{-} \mathrm{CD} 133^{+}$LSCs which was shown to be a significant negative prognostic marker, considering together clinical factors. There is little data regarding IL-23 levels in AML, although IL-23 levels have been reported to be associated with AML leukemogenesis and disease susceptibility in a previous study [36]. Based on our findings, it may be more advantageous to investigate $\mathrm{T}$ helper type 17 (Th17) cell or cell level associations than to monitor cytokines expressed in plasma to understand the association between LSC and Th17.

We applied the gate of CD $45^{\mathrm{dim}}$ population using the same criteria. Also, our results showed that the individual differences were large for CD45 ${ }^{\mathrm{dim}}$ population (Supplementary Fig. 1). In addition, the $\mathrm{CD} 45^{\mathrm{dim}} \mathrm{CD} 34^{+} \mathrm{CD} 38^{-} \mathrm{CD} 133^{+}$cells were prominently detected in the bone marrow of patients with AML and CML, but not in those with DLBCL, MM, MDS, ALL, CLL, and HL (Fig. 4). Moreover, the prognostic significance of LSCs has been reported in previous studies [1, 17]. Tervinjin et al. showed that higher $\mathrm{CD} 34^{+} \mathrm{CD} 45^{-} \mathrm{LAP}^{+}$ cell proportions were related to poor survival [1]. However, our study demonstrated that higher levels of the $\mathrm{CD} 45^{\mathrm{dim}} \mathrm{CD} 34^{+} \mathrm{CD} 38^{-} \mathrm{CD} 133^{+}$cells predict poor OS and EFS in AML (Fig. 5). These results also indicate that the $\mathrm{CD} 45^{\mathrm{dim}} \mathrm{CD} 34^{+} \mathrm{CD} 38^{-} \mathrm{CD} 133^{+}$cell compartment in the bone marrow could help discriminate between LSCs and normal hematopoietic stem cells, and can serve as a strong prognostic marker. Therefore, targeting $\mathrm{CD} 45^{\mathrm{dim}} \mathrm{CD} 34^{+} \mathrm{CD} 38^{-}$ $\mathrm{CD}_{133^{+}}$cells could serve as a novel therapeutic strategy in AML. Future studies will focus on the elimination of the $\mathrm{CD} 45^{\mathrm{dim}} \mathrm{CD} 34^{+} \mathrm{CD} 38^{-} \mathrm{CD} 133^{+}$cells in patients with AML. Also, it needs to make sure that $\mathrm{CD} 45^{\mathrm{dim}} \mathrm{CD} 34^{+}$ $\mathrm{CD}^{-} 8^{-} \mathrm{CD} 133^{+}$cells actually work as LSCs in the future. And it is necessary to assess whether the $\mathrm{CD} 45^{\mathrm{dim}} \mathrm{CD} 34^{+} \mathrm{CD} 38^{-} \mathrm{CD} 133^{+}$cells have the same characteristics as the stem cells. Therefore, our results indicate that $\mathrm{CD} 45^{\mathrm{dim}} \mathrm{CD} 34^{+} \mathrm{CD} 38^{-} \mathrm{CD} 133^{+}$cells have the potential of leukemic stem cells in acute myeloid leukemia. 


\section{Conclusions}

$\mathrm{CD} 45^{\mathrm{dim}} \mathrm{CD} 34^{+} \mathrm{CD} 38^{-} \mathrm{CD} 133^{+}$cells in AML might potentially serve as LSCs. Moreover, the high $\mathrm{CD} 45^{\mathrm{dim}} \mathrm{CD} 34^{+} \mathrm{CD} 38^{-} \mathrm{CD} 133^{+}$cell counts in AML patients served as a significantly poor risk factor for overall and event free survival. In addition, this cell population might represent a novel therapeutic target in AML.

\section{Supplementary information}

Supplementary information accompanies this paper at https://doi.org/10. 1186/s12885-020-06760-1.

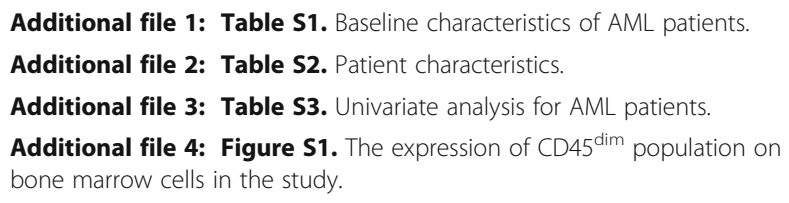

\section{Abbreviations}

BM: Bone marrow; BMCs: Bone marrow cells; HC: Healthy controls; AML: Acute myeloid leukemia; CML: Chronic myeloid leukemia; DLBCL: Diffuse large B-cell lymphoma; MM: Multiple myeloma; MDS: Myelodysplastic syndrome; HL: Hodgkin lymphoma; ALL: Acute lymphocytic leukemia; CLL: Chronic lymphocytic leukemia

\section{Acknowledgments}

Not applicable.

\begin{abstract}
Authors' contributions
SKH, EKN, YC, and JCJ designed the study. SKH, EKN, LJ, JYS and YKJ performed the experiments. SKH, EKN, YKJ, JC, SK, and YJM analyzed and interpreted the experimental data. SKH, EKN, YKJ, JC, SK, and YJM provided the discussion and suggestions to the experiments. SKH, EKN, YC, and JCJ wrote the manuscript with input from all authors. All authors read and approved the final manuscript.
\end{abstract}

\section{Funding}

This study was supported by the Basic Science Research Program of the National Research Foundation of Korea (NRF), funded by the Ministry of Education, Science and Technology (NRF-2017R1A1A3A04069314); and the Biomedical Research Center, funded by the Ulsan University Hospital (UUHBRC-2016-001); and the Korea Health Technology R\&D Project through the Korea Health Industry Development Institute (KHIDI), funded by the Ministry of Health \& Welfare, Republic of Korea (HI17C0904). This work was supported by the Ulsan University Hospital Research Grant (UUH-2019-06).

\section{Availability of data and materials}

All data generated or analyzed during this study are included in this published article and its additional files. Please contact the author Jae-Cheol Jo (jcjo97@hanmail.net) upon reasonable requests.

\section{Ethics approval and consent to participate}

All experiments were performed in accordance with the relevant guidelines and regulations. All patients provided written informed consent before the commencement of the study. The study protocol and patient informed consent form were approved by the Ulsan University Hospital Ethics Committee and Institutional Review Board (UUH-IRB-2016-07-026). The informed written consent was obtained from all included subjects before collecting the bone marrow samples.

\section{Consent for publication}

Not applicable.

\section{Competing interests}

The authors declare that no competing interests exist.

\section{Author details}

${ }^{1}$ Biomedical Research Center, Ulsan University Hospital, University of Ulsan College of Medicine, Ulsan 44033, Republic of Korea. ${ }^{2}$ Department of Hematology and Oncology, Ulsan University Hospital, University of Ulsan College of Medicine, 877 Bangeojinsunhwan-doro, Dong-gu, Ulsan 44033, Republic of Korea.

Received: 2 October 2019 Accepted: 17 March 2020

Published online: 06 April 2020

\section{References}

1. Terwijn M, Zeijlemaker W, Kelder A, Rutten AP, Snel AN, Scholten WJ, Pabst T, Verhoef G, Lowenberg B, Zweegman S, et al. Leukemic stem cell frequency: a strong biomarker for clinical outcome in acute myeloid leukemia. PLoS One. 2014;9:e107587.

2. Laverdiere I, Boileau M, Neumann AL, Frison H, Mitchell A, Ng SWK, Wang JCY, Minden MD, Eppert K. Leukemic stem cell signatures identify novel therapeutics targeting acute myeloid leukemia. Blood Cancer J. 2018;8:52.

3. Chan WI, Huntly BJ. Leukemia stem cells in acute myeloid leukemia. Semin Oncol. 2008;35:326-35.

4. Roboz GJ. Current treatment of acute myeloid leukemia. Curr Opin Oncol. 2012;24:711-9.

5. Angelini DF, Ottone T, Guerrera G, Lavorgna S, Cittadini M, Buccisano F, De Bardi M, Gargano F, Maurillo L, Divona M, et al. A leukemia-associated CD34/CD123/CD25/CD99+ Immunophenotype identifies FLT3-mutated clones in acute myeloid leukemia. Clin Cancer Res. 2015;21:3977-85.

6. Reya T, Morrison SJ, Clarke MF, Weissman IL. Stem cells, cancer, and cancer stem cells. Nature. 2001;414:105-11.

7. Tan BT, Park CY, Ailles LE, Weissman IL. The cancer stem cell hypothesis: a work in progress. Lab Investig. 2006;86:1203-7.

8. van Rhenen A, van Dongen GA, Kelder A, Rombouts EJ, Feller N, Moshaver B, Stigter-van Walsum M, Zweegman S, Ossenkoppele GJ, Jan Schuurhuis G. The novel AML stem cell associated antigen CLL-1 aids in discrimination between normal and leukemic stem cells. Blood. 2007;110:2659-66.

9. van Rhenen A, Moshaver B, Kelder A, Feller N, Nieuwint AW, Zweegman S, Ossenkoppele GJ, Schuurhuis GJ. Aberrant marker expression patterns on the CD34+CD38- stem cell compartment in acute myeloid leukemia allows to distinguish the malignant from the normal stem cell compartment both at diagnosis and in remission. Leukemia. 2007;21:1700-7.

10. Tolba FM, Foda ME, Kamal HM, Elshabrawy DA. Expression of CD133 in acute leukemia. Med Oncol. 2013;30:527.

11. Bonnet D, Dick JE. Human acute myeloid leukemia is organized as a hierarchy that originates from a primitive hematopoietic cell. Nat Med. 1997;3:730-7.

12. Lapidot T, Sirard C, Vormoor J, Murdoch B, Hoang T, Caceres-Cortes J, Minden M, Paterson B, Caligiuri MA, Dick JE. A cell initiating human acute myeloid leukaemia after transplantation into SCID mice. Nature. 1994;367:645-8.

13. Taussig DC, Miraki-Moud F, Anjos-Afonso F, Pearce DJ, Allen K, Ridler C, Lillington D, Oakervee H, Cavenagh J, Agrawal SG, et al. Anti-CD38 antibody-mediated clearance of human repopulating cells masks the heterogeneity of leukemia-initiating cells. Blood. 2008;112:568-75.

14. Park EK, Lee JC, Park JW, Bang SY, Yi SA, Kim BK, Park JH, Kwon SH, You JS, Nam SW, et al. Transcriptional repression of cancer stem cell marker CD133 by tumor suppressor p53. Cell Death Dis. 2015;6:e1964.

15. Wang W, Wang HY, Zhao HX, Cui ZG, Li GL. Expression of CD133 in bone marrow cells of patients with leukemia and myelodysplastic syndrome. Zhongguo Shi Yan Xue Ye Xue Za Zhi. 2007;15:470-3.

16. Reikvam H, Brenner AK, Hagen KM, Liseth K, Skrede S, Hatfield KJ, Bruserud O. The cytokine-mediated crosstalk between primary human acute myeloid cells and mesenchymal stem cells alters the local cytokine network and the global gene expression profile of the mesenchymal cells. Stem Cell Res. 2015;15:530-41.

17. Al-Mawali A, Gillis D, Lewis I. Immunoprofiling of leukemic stem cells CD34+/CD38-/CD123+ delineate FLT3/ITD-positive clones. J Hematol Oncol. 2016;9:61.

18. Hauswirth AW, Florian S, Printz D, Sotlar K, Krauth MT, Fritsch G, Schernthaner GH, Wacheck V, Selzer E, Sperr WR, Valent P. Expression of the target receptor CD33 in CD34+/CD38-/CD123+ AML stem cells. Eur J Clin Investig. 2007;37:73-82.

19. Guenova M, Balatzenko G. CD133-2 (AC141) expression analysis in acute leukemia immunophenotyping in correlation to CD34 and P-glycoprotein. Hematology. 2008;13:137-41. 
20. Binder S, Luciano M, Horejs-Hoeck J. The cytokine network in acute myeloid leukemia (AML): a focus on pro- and anti-inflammatory mediators. Cytokine Growth Factor Rev. 2018;43:8-15.

21. Toren A, Bielorai B, Jacob-Hirsch J, Fisher T, Kreiser D, Moran O, Zeligson S, Givol D, Yitzhaky A, Itskovitz-Eldor J, et al. CD133-positive hematopoietic stem cell "stemness" genes contain many genes mutated or abnormally expressed in leukemia. Stem Cells. 2005;23:1142-53.

22. Mak AB, Nixon AM, Moffat J. The mixed lineage leukemia (MLL) fusionassociated gene AF4 promotes CD133 transcription. Cancer Res. 2012;72: 1929-34.

23. Heo SK, Noh EK, Yoon DJ, Jo JC, Park JH, Kim H. Dasatinib accelerates valproic acid-induced acute myeloid leukemia cell death by regulation of differentiation capacity. PLoS One. 2014;9:e98859.

24. Li P, Ji M, Park J, Bunting KD, Ji C, Tse W. Th17 related cytokines in acute myeloid leukemia. Front Biosci (Landmark Ed). 2012;17:2284-94.

25. Han Y, Ye A, Bi L, Wu J, Yu K, Zhang S. Th17 cells and interleukin-17 increase with poor prognosis in patients with acute myeloid leukemia. Cancer Sci. 2014;105:933-42

26. Morrison SJ, Uchida N, Weissman IL. The biology of hematopoietic stem cells. Annu Rev Cell Dev Biol. 1995;11:35-71.

27. Weissman IL. Stem cells: units of development, units of regeneration, and units in evolution. Cell. 2000;100:157-68.

28. Al-Hajj M, Wicha MS, Benito-Hernandez A, Morrison SJ, Clarke MF. Prospective identification of tumorigenic breast cancer cells. Proc Natl Acad Sci U S A. 2003;100:3983-8.

29. Lu L, Wu M, Sun L, Li W, Fu W, Zhang X, Liu T. Clinicopathological and prognostic significance of cancer stem cell markers CD44 and CD133 in patients with gastric cancer: a comprehensive meta-analysis with 4729 patients involved. Medicine (Baltimore). 2016;95:e5163.

30. Wang Y, Krivtsov AV, Sinha AU, North TE, Goessling W, Feng Z, Zon LI, Armstrong SA. The Wnt/beta-catenin pathway is required for the development of leukemia stem cells in AML. Science. 2010;327:1650-3.

31. Sperr WR, Hauswirth AW, Florian S, Ohler L, Geissler K, Valent P. Human leukaemic stem cells: a novel target of therapy. Eur J Clin Investig. 2004; 34(Suppl 2):31-40

32. Joseph C, Arshad M, Kurozomi S, Althobiti M, Miligy IM, Al-Izzi S, Toss MS, Goh FQ, Johnston SJ, Martin SG, Ellis IO, Mongan NP, Green AR, Rakha EA. Overexpression of the cancer stem cell marker CD133 confers a poor prognosis in invasive breast cancer. Breast Cancer Res Treat. 2019;174(2): 387-99. https://doi.org/10.1007/s10549-018-05085-9.

33. Singh SK, Hawkins C, Clarke ID, Squire JA, Bayani J, Hide T, Henkelman RM, Cusimano MD, Dirks PB. Identification of human brain tumour initiating cells. Nature. 2004;432:396-401.

34. Wu Y, Wu PY. CD133 as a marker for cancer stem cells: progresses and concerns. Stem Cells Dev. 2009;18:1127-34.

35. Carey A, Edwards DK, Eide CA, Newell L, Traer E, Medeiros BC, Pollyea DA, Deininger MW, Collins RH, Tyner JW, et al. Identification of Interleukin-1 by functional screening as a key mediator of cellular expansion and disease progression in acute myeloid leukemia. Cell Rep. 2017;18:3204-18.

36. Qian X, Cao S, Yang G, Pan Y, Yin C, Chen X, Zhu Y, Zhuang Y, Shen Y, Hu Z. Potentially functional polymorphism in IL-23 receptor and risk of acute myeloid leukemia in a Chinese population. PLoS One. 2013;8:e55473.

\section{Publisher's Note}

Springer Nature remains neutral with regard to jurisdictional claims in published maps and institutional affiliations.

Ready to submit your research? Choose BMC and benefit from:
- fast, convenient online submission
- thorough peer review by experienced researchers in your field
- rapid publication on acceptance
- support for research data, including large and complex data types
- gold Open Access which fosters wider collaboration and increased citations
- maximum visibility for your research: over 100M website views per year
At BMC, research is always in progress.
Learn more biomedcentral.com/submissions

